\title{
Integrated flood vulnerability assessment of villages in the Waimanu River Catchment in the South Pacific: the case of Viti Levu, Fiji
}

\author{
Shereen Shabina Begg ${ }^{1}$ (D) Antoine De Ramon $\mathrm{N}^{\prime}$ Yeurt $^{2} \cdot$ Viliamu lese $^{2}$ \\ Received: 24 February 2021 / Accepted: 25 July 2021 \\ (c) The Author(s), under exclusive licence to Springer-Verlag GmbH Germany, part of Springer Nature 2021
}

\begin{abstract}
This paper uses a holistic approach within a catchment scale, through the application of both climatic and non-climatic parameters, to analyze the impacts of river floods on the human security needs of rural riverine communities in the Waimanu Catchment situated in Nausori, Fiji. Consideration of both climatic and non-climatic factors is required since non-climatic factors could be controlled to build resilience against floods. The indicator-based flood vulnerability index methodology is applicable worldwide, but the indicators used in this study were specifically related to the Pacific Island context. In the context of fluvial flood vulnerability, effects of land management and climate change are not mutually exclusive of each other. Consequently, vulnerability assessments should consider the connection between people's actions and ecosystems for the entire catchment area since upstream land use practices influence flood vulnerabilities downstream. In our research, a community-based flood vulnerability index system in conjunction with rainfall variability and land use assessments was used to quantitatively and qualitatively analyze the flood vulnerability, and it was found that increased rainfall, poor agricultural practices, gravel extraction, and improper waste management predominantly increased the exposure and sensitivity of midstream and downstream communities to river floods by modifying river morphology. Midstream communities in the Waimanu Catchment were most vulnerable to river floods due to their very low adaptive capacity in terms of poor ecosystem health and lack of natural resources to cope with the subsequent impacts of floods, being most sensitive to changes in land use and land cover.
\end{abstract}

Keywords Fluvial flood vulnerability $\cdot$ Integrated approach $\cdot$ Land management $\cdot$ Rainfall $\cdot$ Natural resources $\cdot$ Adaptive capacity

Communicated by Tony Weir

Shereen Shabina Begg

shereen.begg@gmail.com

Antoine De Ramon N'Yeurt

antoine.nyeurt@usp.ac.fj

Viliamu Iese

viliamu.iese@usp.ac.fj

1 Pacific Centre for Environment and Sustainable Development (PaCE-SD), The University of the South Pacific (USP), Suva, Fiji

2 PaCE-SD, USP, Suva, Fiji

\section{Introduction}

\section{Characterizing flood events}

Floods are one of the most destructive natural hazards worldwide causing loss of lives, real estate, and infrastructure (Dadson et al. 2017). Floods occur mostly in regions that experience highly variable precipitation and runoff events (Baker 1977; Harlin 1980), and are associated with erosion and the transport of sediments (Judson and Ritter 1964; Wilson 1973) and nutrients into the rivers (Hubbard et al. 2011). Fluvial floods are caused by downstream flow of runoff produced by heavy precipitation on wet ground and occur when the amount of water in the river exceeds its holding capacity (Dadson et al. 2017).

By 2050, ongoing climate change is projected to increase flood risk globally by $187 \%$ (Arnell and Gosling 2016; IPCC 2019) which would aggravate the consequences of floods on 
human life and ecosystems (Kistemann et al. 2002; Arnell and Gosling 2016; Komi et al. 2016). Factors which exacerbate the vulnerability of communities to floods involve geographical features such as flat topography (Mondal et al. 2020), inappropriate utilization of natural resources, for example, improper waste disposal near riverbanks which are transferred into the river system through heavy rainfall and flood events causing siltation and consequently hindering the drainage network of rivers, and failures of institutional frameworks (Hills 2011; Komi et al. 2016). One way to manage flood risks is by reducing the vulnerability of exposed communities (Komi et al. 2016); hence, there is a critical need for flood vulnerability assessments.

An integrated flood vulnerability assessment identifies the catchment area as a dynamic holistic system comprising several fluxes and interactions between land and water (Komi et al. 2016; Dadson et al. 2017; Mondal et al. 2020). Numerous studies have looked at the coupled effects of climate change and land use changes on hydrological regimes (Robson 2002; Abbaspour et al. 2009; Staudt et al. 2013) and highlighted the impacts on downstream communities in terms of increased magnitude and frequency of fluvial floods (Blaikie and Muldavin 2004; Wheater and Evans 2009; Pattison and Lane 2012; Nepal et al. 2014; Komi et al. 2016; Dadson et al. 2017).

\section{Flooding risk in Pacific Islands}

River flooding is a frequent occurrence in high volcanic Pacific Island Countries (PICs) due to high precipitation, small river catchments, and low-lying coastal areas (NDMO 2019). A few studies investigated the impacts of climate change and land use changes on flood intensification in lowland Pacific riverine communities (Terry 2002; Nunn 2009, 2013; Lata and Nunn 2012). The severity of floods is influenced by several factors; these include intensity and duration of rainfall, holding capacity of rivers and drainage networks, and the amount of deforestation in catchment areas which lead to increased runoffs into the rivers.

In Fiji, floods have occasionally occurred outside of the typical wet season (November to April) such as during the months of June to October, due to the impacts of climate change (McGree et al. 2010; Fiji Meteorological Service 2019). Historical records confirm that one of the meteorological causes of major flood events is the southwest displacement of the South Pacific Convergence Zone (SPCZ), and these floods are commonly linked to persistent soil saturation (McGree et al. 2010). On average, Fiji's economy suffers flood losses of approximately US $\$ 9.7$ million per annum, and about ten people die annually due to floods (NDMO 2019). Inundations also lead to health hazards such as the spread of epidemics as a result of leaking septic tanks and improper sewage disposal (NDMO 2019).

Jenkins (2009) highlighted the upstream-downstream linkages within river basins in Fiji and accentuated the impacts of poor land use practices upstream on intensifying downstream floods. In addition to this, a study by Rashni (2020) on the ecological status of the Ba River in Viti Levu, Fiji, proposed land management measures toward achieving riverine resource management. These included avoidances of gravel extraction in rivers and of deforestation and farming on riverbanks and ensuring proper waste management. The Secretariat of the Pacific Community (SPC) had conducted a comparative analysis using land use surveys, participatory rural appraisals, and household income and expenditure surveys of four villages located in the Sabeto Watershed in Nadi, Viti Levu, to assess the impacts of climate variables and natural hazards on their food security (SPC 2016).

Overall, previous studies looked at sector-based vulnerabilities at the water catchment scale. However, every catchment is unique, and the challenges associating the land use and environmental conditions and catchment-scale flood vulnerability differ across catchments. Hence, our study aims at comparatively analyzing fluvial flood vulnerability using an integrated flood vulnerability assessment method. Such a holistic approach within a catchment scale, through the application of both climatic and non-climatic parameters, allows for analyzing the impacts of river floods on human security in general.

\section{The Waimanu Catchment Area, Fiji}

The Waimanu Catchment is located on the windward side of Viti Levu, which is one of the two main islands in the Fiji archipelago. The catchment falls within the NausoriNaitasiri topography and is a sub-catchment of the Rewa Watershed (Atherton et al. 2005). Its total area is $165 \mathrm{~km}^{2}$ (SPC et al. 2012), and it receives one of the highest rainfalls in Fiji (JICA et al. 1998; Nausori Town Council 2012) resulting in a high erosive index of the alluvial soil in the catchment (Tamata et al. 2012; ADB and WAF 2016). Physical features of the catchment such as the steep terrain lead to increased surface runoffs (Morrison and Clarke 1990; ADB and WAF 2016). While the upper catchment area has a steep slope with a maximum elevation of $300 \mathrm{~m}$, the catchment transforms into a mature channel and flood plain slopes as it discharges into the Rewa River (SPC et al. 2012). The Waimanu River has a length of approximately $54 \mathrm{~km}$ (SPC et al. 2012). According to baseline information and climate change projections for the Waimanu Catchment (ADB and WAF 2016), threats include increased frequency of more intense flooding in the low-lying areas of the catchment. 


\section{Study area}

Four communities of the Waimanu Catchment area, Viti Levu, Fiji (Fig. 1), were investigated in this study.

In the context of this study, villages have been classified into upstream (Navatuvula), midstream (Sawani and Vuniniudrovu), and downstream (Navuso) communities depending on their location from the source of the river, irrespective of their elevation above sea level. Upstream community refers to the village located closest to the source of the Waimanu River. Mid-stream communities include villages situated between the upper and downstream communities of the river. Finally, downstream community refers to the village situated farthest away from the source and closest to the mouth of the river. Navuso Village is situated along the Rewa Riverbanks whereas Vuniniudrovu Village is located along the banks of Waimanu River, about $5 \mathrm{~km}$ from Navuso. Sawani Village is situated about $4 \mathrm{~km}$ upriver from Vuniniudrovu; and Navatuvula Village is located further upstream, approximately $5 \mathrm{~km}$ from Sawani. There are no villages located upstream of the Navatuvula Village.

\section{Socio-economic aspects}

Alongside the geographical and physical characteristics of communities, socio-economic features also determine flood risks by affecting flood exposure and coping capacity levels of communities (Qasim et al. 2015; Akhtar et al. 2017).
Socio-economic features of the four villages are summarized in Table A1 in Appendix A of the Supplementary Materials. The Sawani Village is the biggest village having the largest population (349) and number of houses (60). Flood exposure levels increase with larger population concentrated within a village (Hiremath and Shiyani 2013). Villages with a higher population of women, children, and elderly are regarded as more vulnerable since these groups of people have less income and mobility; children and elderly require more care whereas women are mostly responsible for caregiving (Mirza 2011). Despite more youths graduating successfully from secondary school in recent years, the percentage of the population progressing on to post-secondary education is still quite low.

Employment rate influences flood effects on people and the degree of recovery from floods (Cutter et al. 2008). The prominent source of income for the villagers is external employment consisting of government or private sector jobs. Subsistence activities including farming and fishing are secondary sources of livelihood and sustenance for the villagers but are threatened by the impacts of climate change and anthropogenic activities. In iTaukei customary practice, ecosystem management within a catchment area has been of paramount importance for the villagers for centuries; however, there is a lack of implementation of strict customary laws to prohibit the impact of land use activities on the health of ecosystems in these four villages. Due to economic reasons including employment creation and royalty payments, landowners are negligent toward the adverse
Fig. 1 Location of the Waimanu Catchment in Viti Levu, Fiji

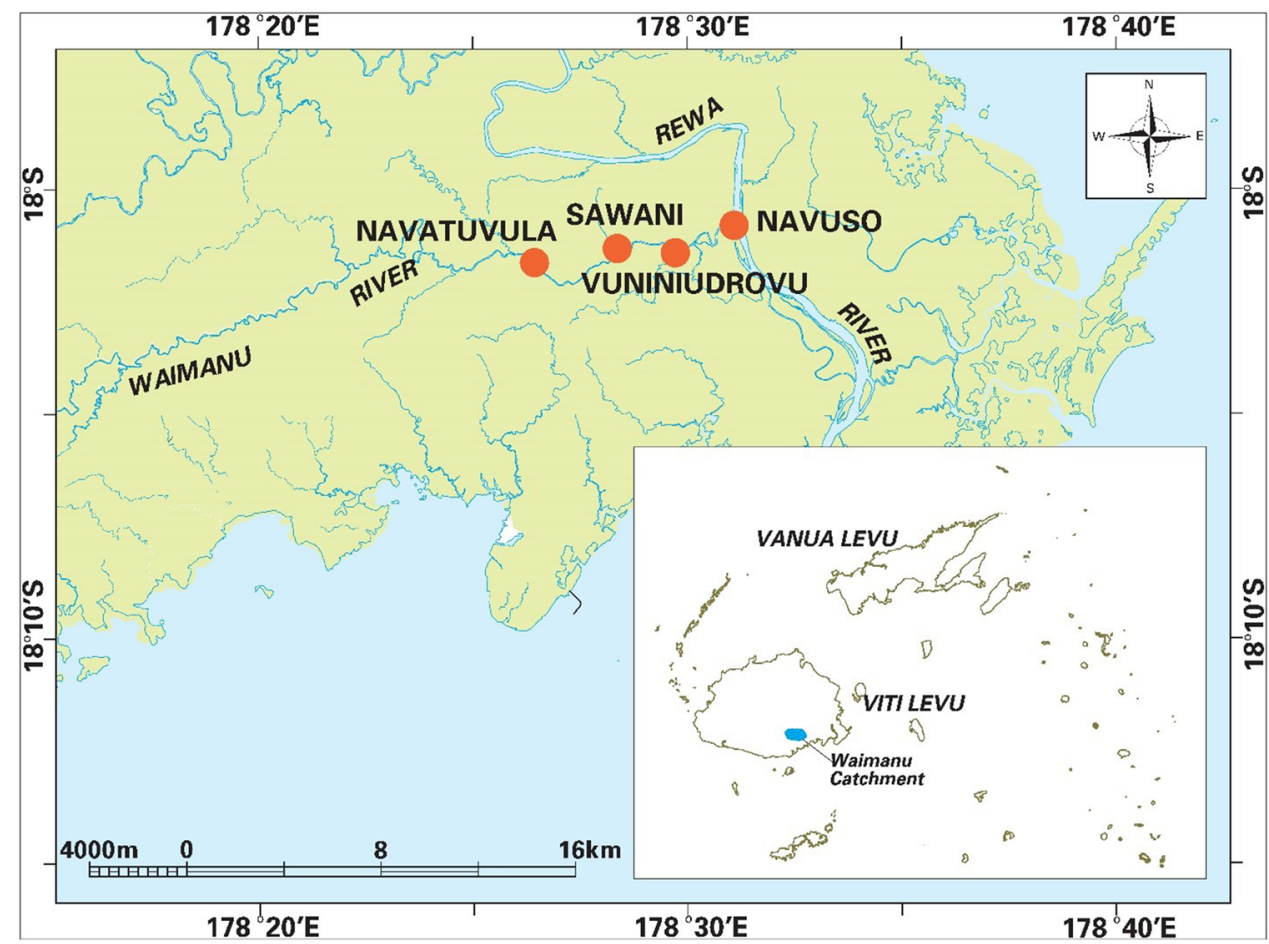


impacts of unsustainable land use practices on the ecosystems and residents in the Waimanu Catchment.

\section{Materials and methods}

\section{Conceptual framework}

In this study, the risk to the villages and people from flooding is described by the IPCC (2014b) as a function of three major dimensions including exposure, sensitivity, and adaptive capacity as follows:

Risk $=f($ exposure, sensitivity, adaptivecapacity)

Exposure is defined as the extent to which a community including its people, livelihoods, ecosystems, resources, and infrastructure, is physically located in a place that could be adversely affected (Adger 2006) by a climate-related hazard, which in this study focuses on floods. Sensitivity refers to the extent of being affected by climate-related stressors (Gallopín 2006; IPCC 2014a). Adaptive capacity is when local communities are able to efficiently use accessible resources to meet their needs in a changing environment (Yohe and Tol 2002; Smit and Wandel 2006; Füssel and Klein 2006; Dumaru and PaCE-SD 2017).

The flood vulnerability index (FVI) which is an indicatorbased approach (Balica et al. 2009) was employed in this study as a tool to assess the risk of flooding. Vulnerability plays a significant role in flood risk assessment as it comprises several economic, social, environmental, physical, and institutional features which affect the susceptibility of the exposed elements to the impact of hazards (UNDRR 2017; Moreira et al. 2021a). However, the terminology and methods used in these assessments are still under debate (Kelman 2018; Aroca-Jiménez et al. 2020). For example, Balica et al. (2009) consider vulnerability to be a function of exposure and sensitivity while other studies distinguish the two concepts by saying that it is possible for an element to be exposed to a hazard and not be vulnerable by having a high adaptive capacity (Fedeski and Gwilliam 2007; Cardona et al. 2012).

Flood vulnerability index is one of the most effective methods of flood vulnerability assessment especially in holistic studies to enable a better representation of reality as it encompasses people's ability to cope, adapt, and respond to hazards in evaluating the potential impacts of flooding (Balica et al. 2013; Nasiri et al. 2016; de Brito et al. 2018; Moreira et al. 2021a, 2021b). It is a parametric approach which aims to build a picture of the vulnerability of an area consequently, assessing the flooding risk of that area by incorporating the four components of flood vulnerability including social, economic, physical, and environmental and their interactions and linking these to the three factors of risk (exposure, sensitivity, and capacity) (Bosher et al. 2007). On the contrary, the deterministic approach has a stronger scientific base and employs physically based modeling methods to assess risks from flooding.

However, rural communities in developing countries including PICs are unable to perform such sophisticated flood risk assessment due to limited availability of scientific data which has led to the introduction of the parametric approach (Balica et al. 2013). The FVI summarizes the complex and multidimensional issues to assist stakeholders in interpreting a phenomenon and making decisions on longterm flood management and prioritizing adaptation (Balica 2012). To avoid misinterpretation, a clear demonstration of the weighting, normalization, and aggregation methods used to construct the index is mandatory (Moreira et al. 2021b). Some studies which have used the FVI comprise Komi et al. (2016) in Nigeria, Karmaoui and Balica (2019) in Morocco, Nazeer and Bork (2019) in Pakistan, Nguyen and Van Nguyen (2019) in Vietnam, and Halavatau et al. (2020) in PICs.

This study selected a set of forty-six indicators using the indicator-based approach to evaluate the flood vulnerability (Balica 2012; SPC et al. 2016; Dumaru and PaCE-SD 2017; Halavatau et al. 2020) for the four communities. All the 46 indicators used in this study were integrated into the respective index for each of the three risk factors. Flood-exposure indicators were divided into two categories. The first set of indicators provided information about the population, infrastructure, location, topography, and land use practices while the second category of indicators supplied information about the degree of climate variations at community level such as the intensity of rainfall and floods (Balica 2012; SPC et al. 2016; Halavatau et al. 2020).

Sensitivity indicators focused on the impact of floods on land, infrastructure, river system, and human health. The Integrated Vulnerability Assessment (IVA) (SPC et al. 2016) and the Participatory Community-based Vulnerability Assessment (Halavatau et al. 2020) frameworks along with other studies consisting of Balica (2012), Komi et al. (2016), and Nazeer and Bork (2019) were used to determine the exposure-sensitivity indicators based on deductive reasoning (Table A2 in Appendix A of the Supplementary Materials). For indicators and parameters on adaptive capacity, refer to Table A3 in Appendix A of the Supplementary Materials.

The Community Integrated Vulnerability Assessment (CIVA) Framework was used to formulate the capacity indicators by assessing the capability of local communities to make effective use of available livelihood assets (LAs) to satisfy their basic human security needs at all times (Dumaru 2010; Warrick et al. 2017). The CIVA Framework was initially developed by the SPC for atoll islands known as the IVA Framework and later improved by the Pacific Centre 
for Environment and Sustainable Development (PaCE-SD) at the University of the South Pacific (USP) to assess vulnerability at community or village levels in PICs (Dumaru and PACE-SD 2017).

The CIVA is built upon three earlier frameworks: the Sustainable Livelihoods Framework, the generic vulnerability framework which pertains to climate-specific vulnerabilities (Polsky et al. 2007; Cardona et al. 2012), and the Disaster Risk Management (DRM) Framework where vulnerability to climate change considers the frequency and intensity of potential hazards such as floods (Cardona et al. 2012). Livelihood assets comprise what a community possesses, i.e., natural resources, infrastructure and services, financial resources, and human skills, and what a community does to achieve its Human Security Objectives (HSOs), i.e., institutions and governance (Thulstrup 2015). The seven HSOs include community health, ecosystem health, security of the community, food security, water security, income security, and energy security (Dumaru and PaCE-SD 2017).

In consideration of the above, thirty-five interacting indicators in accordance with the CIVA narratives were used to determine the adaptive capacity (Table A3 in Appendix A of the Supplementary Materials) of the communities. A subjective scoring system based on a Likert scale adapted and modified from Weis et al. (2016), the CIVA framework (Dumaru and PaCE-SD 2017), and from the normalization method employed by Moreira et al. (2021b), was used to compile the scores of the 46 indicators for each community. These scores were used to compute the mean indices of the three risk factors for every community. Nonetheless, interpretation of the scores (see Table 1) was diverse for exposure and sensitivity elements versus the adaptive capacity element.

\section{Data collection and analysis}

Initially, secondary data was reviewed from journal articles and government reports to identify factors that shaped the vulnerability context of the communities. To apply the integrated flood vulnerability system, three methods were employed to gather both qualitative and quantitative data. These methods encompassed community-based participation, climate variability, and land use assessments. While a community-based assessment was used to gather all three categories of data (exposure, sensitivity, and capacity), climate variability and land use assessment approaches were solely used to attain data on flood exposure. A communitybased vulnerability assessment method allows people who are the ultimate sufferers to reveal their vulnerabilities which provides useful insights in decreasing the vulnerabilities of communities.

The assessment process comprised a 6-week field period which involved conducting focus group discussions and participant observation, data analysis, and finally a follow-up visit to the communities for reporting and verification of research results with the community residents. The focus group discussions conducted in this study were based on a list of questions which included a response scale (Likert scale) to help facilitate the discussions and to gather data on people's perceptions, attitudes, beliefs, and opinions. The researcher and respondents found this response format convenient.

A local research assistant was engaged to ensure familiarity with the local iTaukei (indigenous) language and knowledge of the specific protocols used in approaching the community leaders. Participants reflected a cross-section of gender and livelihoods in the communities. Purposive sampling was vital when targeting only knowledgeable people such as community leaders, elders, teachers, and health workers as reliable sources of information in relation to environmental changes and the impacts on people. The second requirement was that respondents had been continuous residents of the selected communities for at least 30 years. The age category of participants ranged between 30 and 68 years (Table 2).

\section{Exposure data}

Population and household statistics which reveal the number of households and population of the villages adversely affected by floods are provided in Table A1 in Appendix A of the Supplementary Materials. Focus group discussions (see Table 2 in "Data collection and analysis") were used at the local community level (Van Aalst et al. 2008) to attain quantitative data which involved scores of the flood exposure indicators based on people's perceptions. Focus groups
Table 1 Classification of the subjective scores

\begin{tabular}{lll}
\hline Ratings & Interpretation for exposure/sensitivity & Interpretation for adaptive capacity \\
\hline $1-$ Very low & Negligible effect & Needs prioritization \\
$2-$ Low & Least priority action & Needs prioritization \\
$3-$ Medium & Low priority action & Satisfactory but may be included \\
& & in action plans \\
$4-$ High & High priority action & No actions needed \\
$5-$ Very high & Immediate action required & No actions needed \\
\hline
\end{tabular}


Table 2 Number of focus groups and participants for each study site

\begin{tabular}{lllllll}
\hline Village & Focus groups & $\begin{array}{l}\text { Number of } \\
\text { participants } \\
\text { group }\end{array}$ & $\begin{array}{l}\text { Total number } \\
\text { of participants }\end{array}$ & Total males & Total females & Age group \\
\hline Navatuvula & 6 & 5 & 30 & 13 & 17 & $35-60$ \\
Sawani & 9 & 6 & 54 & 29 & 25 & $40-55$ \\
Vuniniudrovu & 7 & 5 & 35 & 16 & 19 & $45-68$ \\
Navuso & 7 & 5 & 35 & 22 & 13 & $30-65$ \\
\hline
\end{tabular}

encompassed both males and females. Besides the proximity of a village from the river, changes in climate variables such as rainfall over time and the floods induced by such changes were perceived by the participants.

Scores for the individual indicators were used to compute the mean exposure index (Table 4 in "Flood exposure"). Participants provided explanations for the scores which are revealed in the subsections of "Flood exposure". Discrepancies between the flood exposure levels of the communities are attributed to the differences in elevation above the mean sea level (Komi et al. 2016; Kablan et al. 2017). Thus, an elevation map (Fig. 2 in "Proximity of villages to the river") was prepared to further demonstrate the exposure of the communities to floods. It portrayed the flood-prone areas within the catchment, and flat land was indicated by contour lines far apart.

Precipitation being a primary parameter relevant to climate change impacts such as floods, rainfall data for a 27-year time period (1994-2020) for the Waimanu Catchment was obtained from the Fiji Meteorological Service. This was the longest period of data available for this station. An analysis of daily rainfall data was performed to identify the number of days each year when rainfall exceeded $100 \mathrm{~mm}$ to determine the rainfall intensity in the catchment (Table 5 in "Frequency and intensity of floods"). Also, biophysical and baseline data for the catchment were collected from the Ministry of Lands and Mineral Resources to compile a geospatial map (Fig. 3 in "Land use and land cover changes") to delineate the land use factors increasing the exposure of the communities to floods. Land use assessment was performed on the basis of the impacts of different categories of land use activities and land cover changes on the frequency and intensity of floods. Selection of the categories of land use activities and land cover changes and their effects on flood vulnerabilities were derived from the literature.

\section{Sensitivity data}

Analogous to the exposure data, scores for flood sensitivity indicators were obtained via the same focus groups (Table 2 in "Data collection and analysis") to compute the mean sensitivity index (Table 6 in "Flood sensitivity index").

\section{Adaptive capacity data}

A community-based participatory assessment approach was exclusively utilized to gather capacity data. While the same focus groups (Table 2 in "Data collection and analysis") were used, questions differed based on the LAs-HSOs indicators. Scores for the 35 indicators (Table A4 in Appendix A of the Supplementary Materials) were used to compute the mean indices of the 5 LAs and 7 HSOs (Table 7 in "Capacity to cope with floods"). The mean indices of the 7 HSOs were averaged further to obtain a single value of capacity index for each community to enable the comparison of adaptive capacity based on human security across the four communities.

\section{Estimation of the flood vulnerability index}

Upon computation of the exposure, sensitivity, and capacity indices, the following equation (Balica et al. 2013) was used to estimate the flood vulnerability in the community-based system:

$\mathrm{FVI}=\frac{(E . S)}{C}$

The FVI equation above, formulated using fractions, provides the most convenient way to simplify the results by producing a single non-dimensional value (Balica and Wright 2009; Balica et al. 2013). Indices produced by the equation are either part of the numerator or denominator, depending on their impact on flood vulnerability, thereby eliminating all units. Exposure-sensitivity indices are placed in the numerator since they increase flood vulnerability, while capacity indices decrease flood vulnerability and so are placed in the denominator (Balica and Wright 2009). Eventually, values of the FVI are categorized into five classes (see Table 3). These values allow easier comparability of FVI across catchments with similar components and scales. The flood vulnerability indices computed for the four villages are depicted in Table 8 in "FVI". 
Table 3 Interpretation of the flood vulnerability index (modified from Balica et al. (2013))

\begin{tabular}{ll}
\hline Index value & Description \\
\hline Less than 1 & Insignificant vulnerability to floods \\
$1-2.5$ & Low vulnerability to floods \\
$2.6-$ & Moderate vulnerability to floods \\
$5.1-7.5$ & High vulnerability to floods \\
$7.6-10$ & Extremely vulnerable to floods \\
\hline
\end{tabular}

\section{Results and discussion}

\section{Flood exposure index}

The majority of the houses in the studied communities have been constructed using corrugated tins, wood, and iron which are mostly composed of discarded materials, indicating lower resilience and higher vulnerability to floods. The water piping system is also susceptible to flood events. The drainage systems run within the villages, and most of the households use these drains as a mode of wastewater disposal from their bathroom and kitchen drain outlets. Vuniniudrovu villagers have to cross the Waimanu River by boat and walk further $200 \mathrm{~m}$ to access the main road since they lack direct road access. The main road (Fig. 2 in "Proximity of villages to the river") located along the Waimanu Riverbanks is prone to heavy rain and flood events. Based on the perceptions of residents, it can be understood that midstream (Sawani and Vuniniudrovu) and downstream (Navuso) communities have a greater exposure to floods (see Table 4) compared to the upstream community (Navatuvula). The rationale for the variant scores is provided in parentheses, and explanations are detailed in the following subsections.

\section{Proximity of villages to the river}

Navatuvula Village has a gentle slope and is located outside the floodplain. Flat land adjacent to rivers represent floodplains. Sawani, Vuniniudrovu, and Navuso villages have a flat topography and are situated in flood hazard zones. The Sawani Church, houses, and assets such as livestock and pig pens in the Sawani Village are located along the Waimanu River. Similarly, houses and infrastructure in the Vuniniudrovu Village are situated adjacent to the Waimanu River; hence, a very high rating of 5 has been allocated. According to the villagers, around $72 \%$ of the houses had relocated inland within the last 5-8 years through mutual collaboration since the northeastern side of the village was being washed away by strong currents caused by heavy rainfall and flood events. Relocation further inland created other issues such as decreased road accessibility, but the village mataqalis (traditional clans) have gathered some money to support road construction. The Ministry of Lands and Mineral Resources has affirmed that Vuniniudrovu is the most low-lying village although Navuso is the most downstream village. Navuso Village is located closer to the Rewa River than Waimanu River and nearer to the river mouth in comparison to other communities. Houses and small agricultural farms in Navuso Village are situated on the Rewa Riverbanks and were described by a rating of 4 by the villagers.

\section{Frequency and intensity of floods}

Since rainfall is a key driver of floods, the positive trend for precipitation over the period of 27 years in the Waimanu Catchment (see Fig. B1 in Appendix B of the Supplementary Materials) and the number of days in each year when rainfall exceeded $100 \mathrm{~mm}$ (see Table 5) coincides with people's perceptions on increased intensity of rainfall (Table 4 in "Flood exposure"). Residents of Navatuvula Village had very rarely experienced occurrence of frequent intense floods; hence, a very low rating was given (1). During heavy rainfall events (in both wet and dry seasons), the Waimanu River overflows its banks, and the Sawani Village gets flooded. Some village elders recall that between 1970 to 1990 water levels in the Waimanu River rose by $0.5 \mathrm{~m}$ due to heavy downpour and floods caused by low pressure and tropical cyclone events. Overall, villagers have observed floods becoming more frequent and intense over the years and thus provided a very high rating of 5 .

Table 4 Scores for flood exposure indicators

\begin{tabular}{|c|c|c|c|c|}
\hline Villages & Navatuvula & Sawani & Vuniniudrovu & Navuso \\
\hline Proximity of village from river & $\begin{array}{l}1 \text { (slightly elevated above } \\
\text { the Waimanu River) }\end{array}$ & $\begin{array}{l}4 \text { (very close proximity } \\
\text { to Waimanu River) }\end{array}$ & $\begin{array}{l}5 \text { (immediately next to } \\
\text { the Waimanu River) }\end{array}$ & $\begin{array}{l}4 \text { (adjacent } \\
\text { to Rewa } \\
\text { River) }\end{array}$ \\
\hline Increased intensity of rainfall & 5 & 5 & 5 & 5 \\
\hline Increased frequency of more intense floods & 1 & 5 & 5 & 3 \\
\hline Average exposure index & 2.3 & 4.7 & 5.0 & 4.0 \\
\hline
\end{tabular}

A high score such as 5 signifies a very high flood exposure whereas a score of 1 indicates the lowest flood exposure. Please refer to Table 1 for more detailed explanation of the scores 


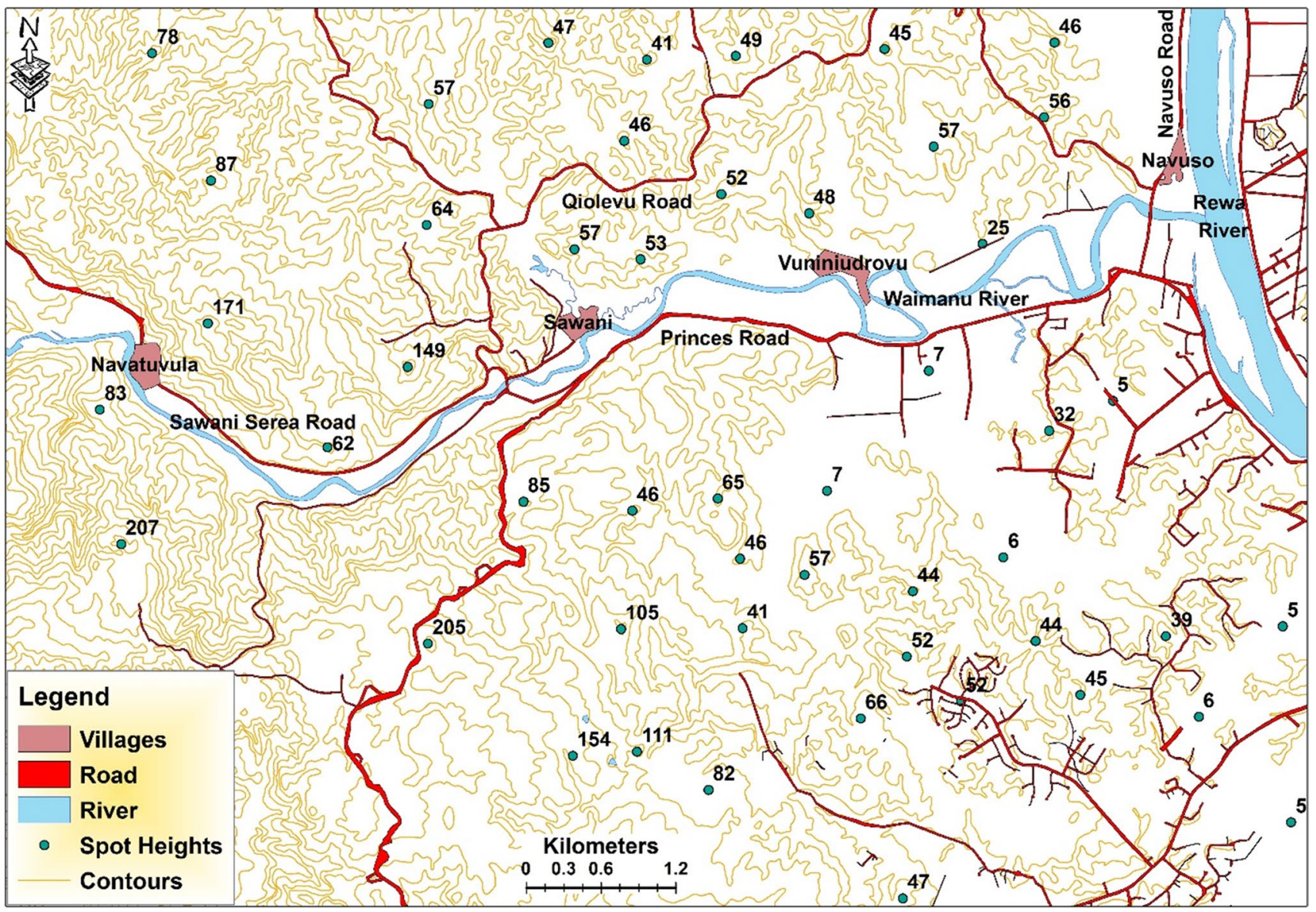

Fig. 2 Elevation map of the villages. Spot heights in meters are indicated

Similar experiences have been faced by the Vuniniudrovu villagers who have also observed that during heavy rainfall and cyclone events, water from the Waimanu River gets pushed back by the Rewa River when it flows down toward the river mouth. Ultimately, both sides of the Vuniniudrovu Village (Southwestern and Eastern) become inundated. Moreover, during periods of heavy rain and floods, villagers are unable to cross the river to reach the main road. It becomes risky for children to go to school and for people to go to work. Floodwaters usually rise up to $1 \mathrm{~m}$ above the feeder road connecting the Waimanu Riverbanks to the main road during the wet season (November to April). Residents of the Navuso Village have occasionally experienced intense flooding subsequent to heavy rainfall events. Intense flooding has been observed in the village during the occurrence of tropical cyclone events when the Rewa River burst its banks. Village compounds and houses become inundated, and crops are damaged during these floods. However, houses have never suffered severe damages. These experiences of the Navuso villagers were revealed through a medium rating of 3 .

\section{Land use and land cover changes}

The geospatial representation of the land tenure and classification of land use and land cover types of the Waimanu Catchment (Fig. 3) demonstrates the exposure of villages to land use practices which increases the flood vulnerability of the villages.

Land use activities are mostly concentrated downstream from Navatuvula Village thus exempting it from the consequences of these activities. The majority of the land use activities and land cover changes happen on the Sawani and Vuniniudrovu riverbanks. Gravel extraction is carried out on $i$ Tauke $i$ areas owned by the mataqali of Sawani Village, as well as on state-reserved areas within the Rewa River. The gravel quarry is located on iTaukei land owned by the mataqali of the Colo-I-Suva Village (situated outside the Waimanu Catchment Area and about $6 \mathrm{~km}$ from Sawani). Besides job creation, quarry partnership of the mataqali of Colo-I-Suva Village, and royalty payments promote gravel extraction activities. Arable farming is predominant in the catchment however; pastoral farming is more prevalent 
Table 5 Number of days each $100 \mathrm{~mm}$ (Data Source: Fiji Meteorological Service (2020)) year when rainfall exceeded

\begin{tabular}{ll}
\hline Year & $\begin{array}{l}\text { No. of days } \\
\text { rainfall exceeded } \\
100 \mathrm{~mm}\end{array}$ \\
\hline 1994 & 2 \\
1995 & 1 \\
1996 & 2 \\
1997 & 2 \\
1998 & 2 \\
1999 & 2 \\
2000 & 2 \\
2001 & 3 \\
2002 & 4 \\
2003 & 3 \\
2004 & 4 \\
2005 & 4 \\
2006 & 4 \\
2007 & 4 \\
2008 & 5 \\
2009 & 5 \\
2010 & 4 \\
2011 & 4 \\
2012 & 5 \\
2013 & 4 \\
2014 & 5 \\
2015 & 6 \\
2016 & 7 \\
2017 & 7 \\
2018 & 6 \\
2019 & 6 \\
2020 & 6 \\
\hline & \\
\hline
\end{tabular}

upstream of Sawani Village. Moreover, areas surrounding riverbanks in midstream communities are mostly grassland rather than riparian forests. Wood wastes such as sawdust, log barks, veneer waste, and wood shavings from the timber sawmill are piled along the riverbank and deposited into the river system during heavy precipitation and flood events. While communal waste pits are available within all four villages, villagers in Navatuvula, Sawani, and Vuniniudrovu still practice indiscriminate dumping of solid household wastes including metal, paper, tins, bottles, and plastics.

\section{Flood sensitivity index}

The extent of being affected by floods has been differently perceived by people in the four villages (see observed impacts in Table 6) depending on their exposure to various stressors consisting of river floods, riverbank erosion, and changes in land cover and land use activities. Midstream communities are most highly affected by flood occurrences with Vuniniudrovu Village being the most sensitive. Brief rationale for the scores is provided in parentheses, and details are elaborated in the following subsections.

\section{Loss of productive land from overbank flooding and riverbank erosion}

Navatuvula villagers have scarcely experienced overbank flooding and riverbank erosion. This is attributed to the dense forest area close to the river. In Sawani and Vuniniudrovu villages, the Waimanu River is shallow with more riverbank erosion taking place due to occurrence of more intense rainfall and overbank flooding. Additionally, village boundary in the Vuniniudrovu Village has decreased and a significant portion of productive land has been lost due to riverbank erosion (expressed by a very high rating of 5). Residents have observed that in the lowest course of the Waimanu River (downstream), erosion occurs the least, and river channel is the widest and deepest allowing a greater flow thus, lessening the tendency of the Waimanu River from overflowing its banks. The Waimanu Riverbanks near the river mouth and the Rewa Riverbanks of Navuso Village are mostly covered with forest which helps enhance the rainwater absorption and retention capacity of soil, thereby reducing the likelihood of erosion. Hence, a low rating of 2 was allocated.

\section{Post-flood effects}

Cascading health hazards are a major consequence of floods. Poor sanitation (improper solid waste and sewage disposal) in conjunction with river floods result in the outbreak of epidemics such as dengue fever and cholera and spread of bacterial diseases including leptospirosis, particularly, in Sawani and Vuniniudrovu villages (revealed by a high rating of 4). Due to the severe impacts of flooding, villagers from Sawani were willing to relocate but faced financial constraints as a result of being the most populated village in the catchment (see Table A1 in Appendix A of the Supplementary Materials). Hence, they are dependent on government intervention. In Navuso Village, such diseases are less common (depicted by a low rating of 2 ) due to a moderate increase in the frequency of more intense floods in comparison to Sawani and Vuniniudrovu villages (Table 4 in "Flood exposure"). Moreover, proper solid waste disposal in Navuso Village prevents the creation of breeding grounds for mosquitoes. Floods also cause damages to houses and infrastructure, especially roads. Both Sawani and Vuniniudrovu villages suffered significant damages to houses. Road erosion primarily occurred on the main road along the Sawani and Vuniniudrovu areas. Vuniniudrovu Village also suffered damages to water pipes during extreme flood events; consequently, ratings of 4 and 5 have been allocated to Sawani and Vuniniudrovu villages, respectively. Navuso villagers on 


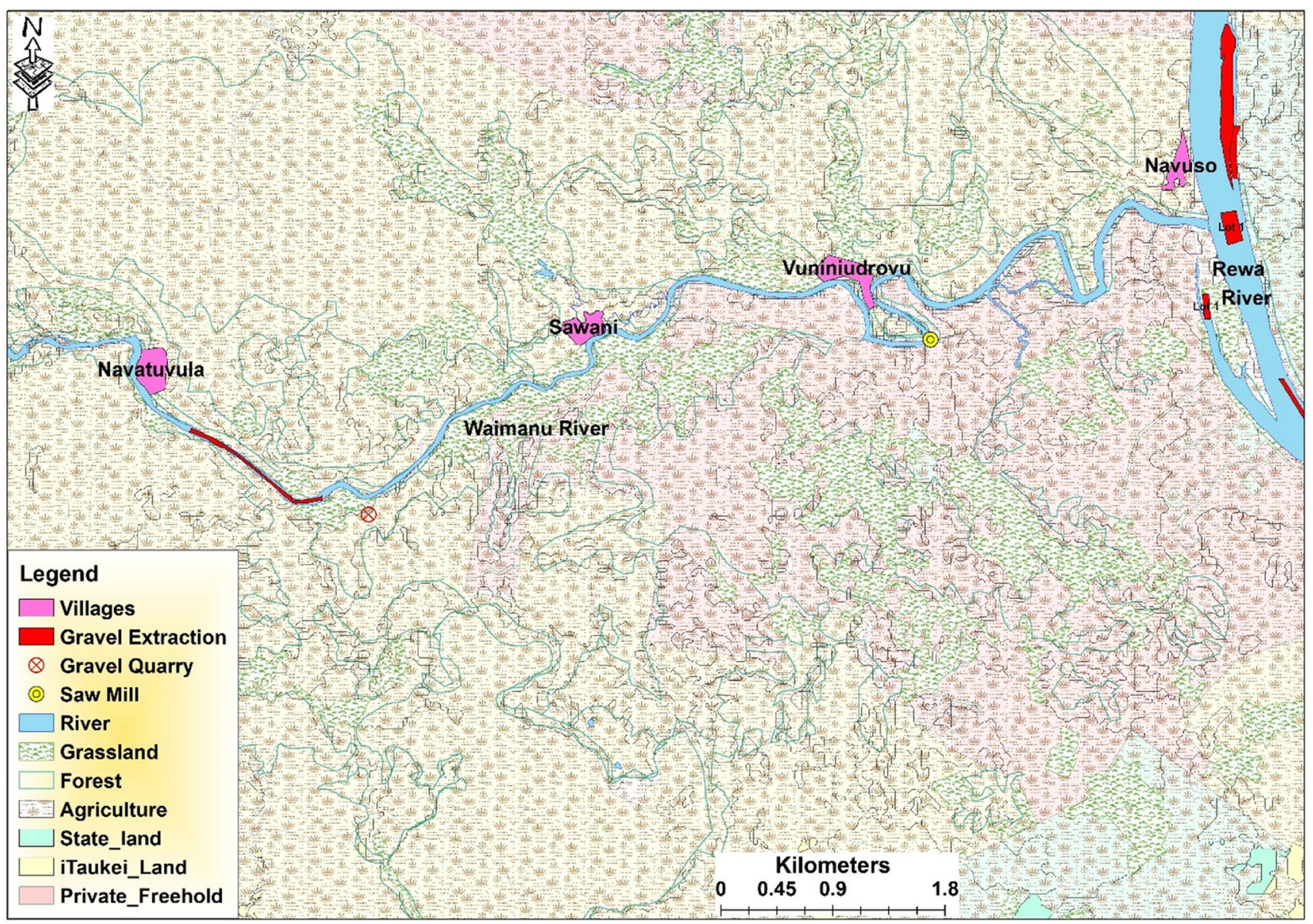

Fig. 3 Geospatial map of the Waimanu Catchment

the other hand have experienced minor damages to houses and the main road during extreme flood events (revealed by a low rating of 2).

\section{River System}

Land is left vacant upon expiry of land leases, promoting the growth of invasive species such as the African tulip tree (Spathodea campanulata), which displaces native forest in Pacific Islands including Fiji (Auld and Nagatalevu-Seniloli 2003). Increased cattle farming leads to heavy grazing of pasture and a reduction in vegetation cover, with a consequent increase in riverbank poaching which contributes to erosion during rainfall and flood events. Cutting down trees for fuelwood and frequent land clearing to establish new plantations further degrade the soil structure and lower its infiltration capacity. Land cover changes, poor agricultural practices, and gravel extraction therefore contribute to increased runoffs and riverbank erosion causing river channel instability and increased suspended sediment conveyance downstream (Nath 2008; ADB and WAF 2016). Hence, both midstream communities along with the downstream community are highly affected by increased sedimentation from gravel extraction and agriculture (depicted by a rating of 4). Although midstream and downstream communities alike suffer the effects of crude dumping, Sawani Village does not experience siltation effects from wood wastes because it is located upstream from the sawmill (represented by a medium rating of 3). However, Vuniniudrovu and Navuso villages endure siltation effects from wood wastes leading to a high rating of 4. Villagers in Sawani and Vuniniudrovu have reported that increased sedimentation and siltation have increased the frequency of floods during heavy rainfall events.

\section{Capacity to cope with floods}

Table 7 highlights the prevailing factors that defy the ability of communities to meet their Human Security Objectives (HSOs) based on their livelihood assets (LAs). All scores below 3 ( 1 and 2 ) indicate areas that require urgent action. Ecosystem health of all communities is weakest 
Table 6 Scores for flood sensitivity indicators

\begin{tabular}{|c|c|c|c|c|}
\hline Villages & Navatuvula & Sawani & Vuniniudrovu & Navuso \\
\hline $\begin{array}{l}\text { Loss of productive land from over- } \\
\text { bank flooding and riverbank erosion }\end{array}$ & 1 & $\begin{array}{l}4 \text { (overbank flooding and } \\
\text { riverbank erosion are fre- } \\
\text { quent and intense during } \\
\text { heavy rainfall) }\end{array}$ & $\begin{array}{l}5 \text { (overbank flooding } \\
\text { and riverbank erosion } \\
\text { is frequent and intense } \\
\text { during heavy rainfall) }\end{array}$ & $\begin{array}{l}2 \text { (overbank flooding is } \\
\text { rare and riverbank ero- } \\
\text { sion does not occur) }\end{array}$ \\
\hline $\begin{array}{l}\text { Emergence of mosquito-borne, water- } \\
\text { borne and bacterial diseases }\end{array}$ & 1 & 4 & 4 & 2 \\
\hline $\begin{array}{l}\text { Damages to houses, road and water } \\
\text { pipes }\end{array}$ & 1 & $\begin{array}{l}4 \text { (houses and main road } \\
\text { suffer damages) }\end{array}$ & $\begin{array}{l}5 \text { (houses, main road } \\
\text { and water pipes are } \\
\text { damaged) }\end{array}$ & $\begin{array}{l}2 \text { (minor damages to } \\
\text { houses and main road) }\end{array}$ \\
\hline $\begin{array}{l}\text { Increased sedimentation in Waimanu } \\
\text { River due to gravel extraction and } \\
\text { poor agricultural practices }\end{array}$ & $\begin{array}{l}1 \text { (no extraction or } \\
\text { agricultural activi- } \\
\text { ties taking place } \\
\text { above the } \\
\text { village) }\end{array}$ & 4 & 4 & 4 \\
\hline $\begin{array}{l}\text { Increased siltation in Waimanu River } \\
\text { due to wood wastes resulting from } \\
\text { timber sawmill, and from crude } \\
\text { dumping of solid household wastes }\end{array}$ & 1 & 3 & 4 & 4 \\
\hline Average sensitivity index & 1 & 3.8 & 4.4 & 2.8 \\
\hline
\end{tabular}

A high score such as 5 signifies very high flood sensitivity whereas a score of 1 indicates the lowest flood sensitivity. Please refer to Table 1 for more detailed explanation of the scores

of the seven HSOs. Community health is also deficient in all communities, since garbage collection services and connection of villages to a sewer system are not provided, indicating weak governance in provisioning proper waste management services. Improper sanitation coupled with flood occurrences further jeopardizes the health of middle and downstream communities. The security of mid and downstream communities is threatened due to being situated in floodplains and exposed to stressors including river floods, riverbank erosion, and land use practices. Vuniniudrovu Village is most vulnerable in terms of security of place and community health followed by Sawani and Navuso. Vuniniudrovu Village also lacks direct access to main roadways even during pre-flood conditions in comparison to all other villages.

Households in all villages have access to piped water and electricity services. Navatuvula and Navuso villages have satisfactory food and income securities through diverse sources. However, income security is low for Sawani and Vuniniudrovu villages owing to less freshwater fishery resources found in the shallow Waimanu River. Therefore, community health, housing, and income security are influenced by the poor health of the ecosystem, which is principally ascribed to weaknesses in natural resources. The ecosystem health of the Sawani and Vuniniudrovu villages is the lowest. Removal of natural resources such as forests and coastal vegetation to establish agricultural farms and commercial (gravel extraction and sawmill) activities in upstream and midstream communities have substantially diminished the coping capacity of midstream communities to floods.

\section{FVI}

Considering the classification provided in Table 3 in "Estimation of the flood vulnerability index", the flood vulnerability in both Sawani and Vuniniudrovu villages (midstream) is high, the latter being extremely vulnerable (see Table 8). Navuso Village has a moderate level of flood vulnerability. While the lowest FVI was estimated at Navatuvula Village (0.71), Vuniniudrovu Village recorded the highest FVI (8.18). The relative heterogeneity of flood vulnerability between the upstream and midstream communities is associated with the high exposure and low coping capacity of midstream communities which increase their sensitivity to floods (see Fig. B2 in Appendix B of the Supplementary Materials). These are primarily triggered by occurrence of land use activities (farming and clearing) and changes in land cover near riverbanks affecting the quantity and quality of natural resources in midstream communities.

\section{Connectivity of the system}

All villages within the catchment area experienced increased intensity of rainfall while occurrence of intense floods and land use changes was more localized in nature. Upstreammidstream-downstream linkages play a vital role in determining the level of flood vulnerability of communities (Liu and Shi 2017) in a catchment area since land use activities contributing to flood vulnerability in midstream (Sawani and Vuniniudrovu) communities occur both within and outside 
Table 7 Average indices of livelihood assets and Human Security Objectives of the four villages

\begin{tabular}{lllll}
\hline & Navatuvula & Sawani & Vuniniudrovu & Navuso \\
\hline Livelihood assets: & & & & \\
$\quad$ Natural resources & 3.7 & 2.1 & 2.0 & 2.6 \\
$\quad$ Infrastructure and services & 3.0 & 2.7 & 2.4 & 2.6 \\
$\quad$ Financial resources & 3.0 & 2.7 & 2.7 & 3.0 \\
Human skills & 3.0 & 3.1 & 3.1 & 3.1 \\
$\quad$ Institutions and governance & 3.4 & 3.1 & 3.1 & 3.1 \\
Human Security Objectives: & & & & \\
Ecosystem health & 2.8 & 1.8 & 1.8 & 2.0 \\
Community health & 2.8 & 2.6 & 2.4 & 2.6 \\
Security of place & 3.0 & 2.2 & 2.0 & 3.2 \\
Food security & 3.4 & 3.0 & 3.0 & .3 .0 \\
Water security & 3.8 & 3.2 & 3.0 & 3.6 \\
Energy security & 3.8 & 3.8 & 3.8 & 3.0 \\
Income security & 3.0 & 2.8 & 2.8 & \\
\hline
\end{tabular}

Please refer to Table 1 for a detailed explanation of the scores (upstream in Navatuvula Village) the scope of the communities. Navatuvula Village was not vulnerable to flooding, but land use activities happening there increased the flood vulnerability of midstream communities which undertook majority of the land use activities and were the most vulnerable to flooding. Finally, Navuso Village (downstream) was the least involved in land use changes, yet had a moderate vulnerability to flooding attributed to upstream activities.

Land use changes comprising of gravel extraction, poor agricultural practices, deforestation, and improper waste disposal from the timber sawmill and households along the river adversely affect river water quantity through flow disruptions and increased runoffs, and water quality in terms of erosion, siltation, sedimentation, and pollution (DeFries and Eshleman 2004; Wishart et al. 2008; Asamoah et al. 2020). These land use practices have been construed to be the key causes of decreased resilience of various riverine communities including the Waimanu Catchment (ADB and WAF 2016) to future floods (Woodward et al. 2016) by amplifying the impacts of climate variability. Eventually, land management in rural catchment areas would prove to be a means to reduce midstream and downstream flood vulnerability (Pattison and Lane 2011).

Land use practices in the catchment were an indication of poor handling of the situation by riverine communities, coupled with a lack of belief in human capacity to cope with new perils. Likewise, landowners (resident or non-resident)

Table 8 Computed flood vulnerability indices of the four villages

\begin{tabular}{lllll}
\hline Villages & Navatuvula & Sawani & Vuniniudrovu & Navuso \\
\hline Vulnerability index & 0.71 & 6.45 & 8.18 & 3.88 \\
\hline
\end{tabular}

were apathetic about the impacts of land use practices which were undertaken on their land. The results of this study accentuate the need for non-structural measures for reducing the drastic impacts of floods in the most vulnerable (midstream) communities where participation of local residents throughout the catchment area must be paramount.

\section{Ecosystem health — key adaptive capacity component}

All villages had poor ecosystem health; however, Sawani and Vuniniudrovu were the most unfortunate ones due to their limited access to natural resources. This lack of resources was ascribed to concentration of land use activities and land cover changes being most prominent on riverbanks within these areas, resulting in the destruction of natural ecosystems. Midstream communities were contributing to their own vulnerabilities but the scale of vulnerability differed across the villages depending on their exposure and sensitivity to floods. Reduction in natural resources increased the sensitivity of midstream communities to floods by deteriorating their coping capacity. Besides catering for livelihoods and sustenance, maintenance and sustainability of ecosystem health is vital in reducing flood vulnerabilities toward combatting the impacts of climate change.

\section{The need for a holistic approach}

For a better comprehension of fluvial flood vulnerability, it is critical to use an integrated approach to assess flood vulnerability and help to analyze various components of risk comprising exposure, sensitivity, and adaptive capacity. Considering both climatic and non-climatic factors is essential, since non-climatic factors can be manipulated to reinforce 
resilience against floods. Evaluation of climate variables such as rainfall is mandatory in assessing flood exposure of communities, apart from simply measuring the distribution of dwellings in a floodplain. Likewise, land use assessment and geospatial mapping on a catchment scale is essential in determining the location of various stressors within the catchment and their role in exacerbating the exposure of the socio-geospatial framework to flooding.

Using a mixed-method approach helps to get a more holistic representation of flood vulnerability among communities within a catchment area. Without employing a comparative analysis at the individual community level, it would be difficult to determine the factors that aggravate the existing vulnerabilities from climate change. In order to reduce the extreme impacts of floods and to build resilience by strengthening the coping capacity of a community, proper assessment of adaptive capacity is obligatory. This is possible through measurement of the ability of communities to meet their human needs by converting their LAs into positive livelihood outcomes. The seven HSOs feature the basic needs of people and eventually help apprehend the coping capacity of individual communities in an effective manner. Using the sustainable livelihood approach (Thulstrup 2015) helps in identifying the low HSOs and the related weak LAs which require amelioration.

\section{Knowledge gaps}

The indicator-based FVI methodology is applicable in a global context (Komi et al. 2016; Nazeer et al. 2019; Halavatau et al. 2021; Karmaoui and Balica 2021; Nguyen and Van Nguyen 2021). However, the indicators used in this study were specifically related to the Pacific Island context and could be applied to other local and regional catchments with similar socio-economic and geographic characteristics. Such locations are numerous in the larger Pacific Islands with steep terrains experiencing high rainfall which produce high runoffs making them susceptible to flooding (UNEP 2012). This would allow us to comprehend the holistic vulnerability of communities by recognizing the factors of exposure and sensitivity, as well as the dimensions of adaptive capacity.

Contemplating the connectivity within a catchment area, i.e., the upstream-downstream linkages, would contribute to a better flood vulnerability assessment and flood risk management in different regions of the world. This study also emphasizes on the role of ecosystems in enhancing the adaptive capacities of communities to help reduce their vulnerability to floods. This finding is crucial in global context especially in catchment areas which are subject to intense land use and land cover changes. An exhaustive quantitative analysis of the flood vulnerability scores could help to better diagnose the issues at the community level; for example, a score of 3 is considered satisfactory when evaluating adaptive capacity.

However, it has not been detailed in this study whether future refinements would still be needed in those areas to enhance the human security and livelihood outcomes of the communities. In addition, proper data collection on flood frequency and intensity such as a flood map simulated using a hydraulic model to estimate the flood depth of communities similar to Komi et al. (2016) could provide additional scientific knowledge on flood hazard to support adaptation designs besides the participatory research approach employed for flood vulnerability assessment in this study which supports high-level decision-making processes (Balica 2012; SPC et al. 2016; Halavatau et al. 2020). Contemplation of traditional knowledge could also help build resilience to the increasing impacts of climate change including risks from flooding by strengthening the adaptive capacity of communities (Weir et al. 2017; Weir and Pittock 2017).

\section{Conclusions}

In the context of fluvial flood vulnerability, the effects of land management and climate change are not mutually exclusive of each other. Consequently, vulnerability assessments should consider the connection between people's actions and ecosystems for the entire catchment area, since upstream land use practices influence flood vulnerabilities downstream. In our research, a community-based FVI system in conjunction with rainfall variability and land use assessments was used to quantitatively and qualitatively analyze the vulnerability to flooding, and it was found that increased rainfall, poor agricultural practices, gravel extraction, and improper waste management predominantly increased the exposure and sensitivity of midstream and downstream communities to floods by modifying the river morphology. Midstream communities were most vulnerable to river flooding as a result of having the lowest adaptive capacity in terms of poor ecosystem health and lack of natural resources to cope with the impacts of floods, while being the most sensitive to changes in land use and land cover. To decrease the vulnerability of midstream communities to fluvial floods, environmental awareness and capacity-building must be provided in all communities to encourage better land management practices throughout the catchment. Moreover, provision of municipal services such as regular garbage collection and sewerage lines should be made to reduce ecosystem degradation, ensure proper health and sanitation, and avert the increase of flood vulnerability. 
Supplementary Information The online version contains supplementary material available at https://doi.org/10.1007/s10113-021-01824-9.

Acknowledgements The authors express sincere gratitude to Mr. Manjoor Begg for his research assistance during the field work at the study sites. We would also like to acknowledge the Research Office at the University of the South Pacific for awarding the Pacific Scholarship for Excellence in Research and Innovation (PSERI) to Shereen Shabina Begg which helped to fund this study. We also thank the Fiji Ministry of Lands and Mineral Resources for providing mapping assistance in the study.

\section{Declarations}

Ethics approval and consent to participate The researcher obtained respective informed consent from the village heads and participants prior to conducting the focus group discussions in the field.

Conflict of Interest The authors declare no competing interests.

\section{References}

Abbaspour KC, Faramarzi M, Ghasemi SS, Yang H (2009) Assessing the impact of climate change on water resources in Iran. Water Resour Res 45:W10434. https://doi.org/10.1029/2008WR007615

ADB, Water Authority of Fiji (WAF) (2016) Fiji: urban water supply and wastewater management project, Rewa River water supply subproject (Environmental Assessment Project No. 49001-002). Asian Development Bank, Suva. https://www.adb.org/sites/defau lt/files/linked-documents/49001-002-ieeab.pdf. Accessed 13 Mar 2020

Adger WN (2006) Vulnerability Global Environ Chang 16:268-281. https://doi.org/10.1016/j.gloenvcha.2006.02.006

Akhter MI, Irfan M, Shahzad N, Ullah R (2017) Community based flood risk reduction: a study of 2010 floods in Pakistan. Am J Soc Sci Res 3: 35-42. http://www.aiscience.org/journal/ajssr

Arnell NW, Gosling SN (2016) The impacts of climate change on river flood risk at the global scale. Clim Chang 134:387-401. https:// doi.org/10.1007/s10584-014-1084-5

Aroca-Jiménez E, Bodoque JM, García JA (2020) How to construct and validate an Integrated Socio-Economic Vulnerability Index: implementation at regional scale in urban areas prone to flash flooding. Sci Total Environ 746:140905. https://doi.org/10.1016/j. scitotenv.2020.140905

Asamoah O, Kuittinen S, Abrefa Danquah J, Quartey ET, Bamwesigye D et al (2020) Assessing wood waste by timber industry as a contributing factor to deforestation in Ghana. Forests 11:939. https:// doi.org/10.3390/f11090939

Atherton J, Olson D, Farley L, Qauqau I (2005) Fiji watersheds at risk: watershed assessment for healthy reefs and fisheries (Final Report to the United States Department of State OESI Grant\# SFJ600, 4). Wildlife Conservation Society, Suva. https://fiji.wcs.org/Porta 1s/82/2005_Atherton_Fiji $\% 20$ watersheds\%20at\%20risk-\%20Wat ershed $\% 20$ assessment $\% 20$ for $\% 20$ healthy $\% 20$ reefs $\% 20$ and $\% 20$ fis heries.pdf. Accessed on 21 Mar 2020

Auld BA, Nagatalevu-Seniloli M (2003) African tulip tree in the Fijian Islands. In: Labrada R (ed) Weed Management for Developing Countries, Chapter 2. Problem weeds and their management in crops and non-crop situations. FAO Plant Production and Protection Paper 120 Add. 1. Rome, ISBN 92-5-105019-8
Baker VR (1977) Stream-channel response to floods, with examples from central Texas. Geol Soc Am Bull 88:1057-1071. https://doi. org/10.1130/0016-7606(1977)88\%3c1057:SRTFWE\%3e2.0.CO;2

Balica SF (2012) Applying the flood vulnerability index as a knowledge base for flood risk assessment. Dissertation, IHE Delft Institute for Water Education. https://repository.tudelft.nl/islandora/object/ uuid\%3Ad790ad77-0592-4459-bb21-08075491a2be. Accessed on $27 \mathrm{Feb} 2020$

Balica SF, Douben N, Wright NG (2009) Flood vulnerability indices at varying spatial scales. Water Sci Technol 60:2571-2580. https:// doi.org/10.2166/wst.2009.183

Balica SF, Popescu I, Beevers L, Wright NG (2013) Parametric and physically based modelling techniques for flood risk and vulnerability assessment: a comparison. Environ Model Softw 41:84-92. https://doi.org/10.1016/j.envsoft.2012.11.002

Balica SF, Wright NG (2009) A network of knowledge on applying an indicator-based methodology for minimizing flood vulnerability. Hydrol Process 23:2983-2986. https://doi.org/10.1002/hyp.7424

Blaikie PM, Muldavin JS (2004) Upstream, downstream, China, India: the politics of environment in the Himalayan region. Ann Assoc Am Geogr 94:520-548. https://doi.org/10.1111/j.1467-8306. 2004.00412.x

Bosher L, Dainty A, Carrillo P, Glass J (2007) Built-in resilience to disasters: a pre-emptive approach. Eng Constr Archit Manag 14:434-446. https://doi.org/10.1108/09699980710780746

de Brito MM, Evers M, Almoradie ADS (2018) Participatory flood vulnerability assessment: a multi-criteria approach. Hydrol Earth Syst Sci 22:373-390. https://doi.org/10.5194/hess-22-373-2018

Cardona OD, Van Aalst MK, Birkmann J, Fordham M, McGregor G et al (2012) Determinants of risk: exposure and vulnerability. In: Field CB, Barros V, Stocker TF, Qin D, Dokken DJ, Ebi KL, Mastrandrea MD, Mach KJ, Plattner GK, Allen SK, Tignor M, Midgley PM (eds) Managing the risks of extreme events and disasters to advance climate change adaptation: a special report of working groups I and II of the Intergovernmental Panel on Climate Change (IPCC). Cambridge University Press, Cambridge, United Kingdom and New York, pp 65-108. https://www.ipcc.ch/site/assets/uploads/2018/03/ SREX-Chap2_FINAL-1.pdf. Accessed on 17 May 2021

Cutter SL, Barnes L, Berry M, Burton C, Evans E et al (2008) A placebased model for understanding community resilience to natural disasters. Glob Environ Chang 18:598-606. https://doi.org/10. 1016/j.gloenvcha.2008.07.013

Dadson SJ, Hall JW, Murgatroyd A, Acreman M, Bates P et al (2017) A restatement of the natural science evidence concerning catchmentbased 'natural' flood management in the UK. Proc Math Phys Eng Sci 473:20160706. https://doi.org/10.1098/rspa.2016.0706

DeFries R, Eshleman KN (2004) Land-use change and hydrologic processes: a major focus for the future. Hydrol Process 18:21832186. https://doi.org/10.1002/hyp.5584

Dumaru P (2010) Community-based adaptation: enhancing community adaptive capacity in Druadrua Island, Fiji. Wiley Interdiscip Rev Clim Chang 1:751-763. https://doi.org/10.1002/wcc.65

Dumaru P, Pacific Centre for Environment and Sustainable Development (PaCE-SD) (2017) The Pacific Islands community framework for integrated vulnerability assessment: an implementation guide for Pacific resilience practitioners. University of the South Pacific, Suva. https://pace.usp.ac.fj/eugcca-knowledge-centre/ publications/. Accessed on 11 Jan 2020

Eakin H, Luers AL (2006) Assessing the vulnerability of socialenvironmental systems. Annu Rev Environ Resour 31:365-394. https://doi.org/10.1146/annurev.energy.30.050504.144352

Fedeski M, Gwilliam J (2007) Urban sustainability in the presence of flood and geological hazards: the development of a GIS-based vulnerability and risk assessment methodology. Landsc Urban Plan 83:50-61. https://doi.org/10.1016/j.landurbplan.2007.05.012 
Füssel HM, Klein RJ (2006) Climate change vulnerability assessments: an evolution of conceptual thinking. Clim Change 75:301-329. https://doi.org/10.1007/s10584-006-0329-3

Gallopín GC (2006) Linkages between vulnerability, resilience, and adaptive capacity. Glob Environ Chang 16:293-303. https://doi. org/10.1016/j.gloenvcha.2006.02.004

Halavatau S, Susumu G, Solofa D, Salele ET, Mateboto J et al (2020) Participatory Community-based Vulnerability Assessment Framework. SPC, Suva. https://spccfpstore1.blob.core. windows.net/digitallibrary-docs/files/20/201d1da24cd3229 01ffdefef9b9c2982.pdf?sv =2015-12-11\&sr=b\&sig $=\mathrm{dGO} 91$ hA\%2FBqYJSakWeenjRtkN2UvapwY3YcWL1nKJ\%2Bhw\% $3 \mathrm{D} \& \mathrm{se}=2021-12-15 \mathrm{~T} 03 \% 3 \mathrm{~A} 53 \% 3 \mathrm{~A} 00 \mathrm{Z} \& \mathrm{sp}=\mathrm{r} \& \mathrm{rscc}=\mathrm{pub}-$ lic\%2C\%20max-age\%3D 864000\%2C\%20max-stale\%3D864 00\&rsct=application $\% 2$ Fpdf \& rscd=inline $\% 3 \mathrm{~B} \% 20$ filename $\%$ 3D\%22Participatory_Community_based_Vulnerability_Asses sment_Framework.pdf\%22. Accessed on 10 Aug 2020

Harlin JM (1980) The effect of precipitation variability on drainage basin morphometry. Am J Sci 280:812-825. https://doi.org/10. 2475/ajs.280.8.812

Hiremath DB, Shiyani RL (2013) Analysis of vulnerability indices in various agro-climatic zones of Gujarat. Indian J Agric Econ 68:122-137. https://doi.org/10.22004/ag.econ.206326

Hubbard L, Kolpin DW, Kalkhoff SJ, Robertson DM (2011) Nutrient and sediment concentrations and corresponding loads during the historic June 2008 flooding in eastern Iowa. J Environ Qual 40:166-175. https://doi.org/10.2134/jeq2010.0257

IPCC (2014a) Annex II: Glossary [Agard J, Schipper ELF, Birkmann J, Campos M, Dubeux C, Nojiri Y, Olsson L, Osman-Elasha B, Pelling M, Prather MJ, Rivera-Ferre MG, Ruppel OC, Sallenger A, Smith KR, St. Clair AL, Mach KJ, Mastrandrea MD, Bilir TE (eds)]. In: Barros VR, Field CB, Dokken DJ, Mastrandrea MD, Mach KJ, Bilir TE, Chatterjee M, Ebi KL, Estrada YO, Genova RC, Girma B, Kissel ES, Levy AN, MacCracken S, Mastrandrea PR, White LL (eds) Climate Change 2014: Impacts, Adaptation, and Vulnerability. Part B: Regional Aspects. Contribution of Working Group II to the Fifth Assessment Report of the Intergovernmental Panel on Climate Change. Cambridge University Press, Cambridge, United Kingdom and New York, pp 1757-1776. https://www.ipcc.ch/site/assets/uploads/2018/ 02/WGIIAR5-AnnexII_FINAL.pdf. Accessed on 14 May 2021

IPCC (2014b) Summary for policymakers. In: Field CB, Barros VR, Dokken DJ, Mach KJ, Mastrandrea MD, Bilir TE, Chatterjee M, Ebi KL, Estrada YO, Genova RC, Girma B, Kissel ES, Levy AN, MacCracken S, Mastrandrea PR, White LL (eds) Climate Change 2014: Impacts, Adaptation, and Vulnerability. Part A: Global and Sectoral Aspects. Contribution of Working Group II to the Fifth Assessment Report of the Intergovernmental Panel on Climate Change. Cambridge University Press, Cambridge, United Kingdom and New York, pp 1-32. https://www.ipcc.ch/ site/assets/uploads/2018/02/ar5_wgII_spm_en.pdf. Accessed on 14 June 2021

IPCC (2019) Summary for Policymakers. In: Pörtner HO, Roberts DC, Masson-Delmotte V, Zhai P, Tignor M, Poloczanska E, Mintenbeck K, Nicolai M, Okem A, Petzold J, Rama B, Weyer $\mathrm{N}$ (eds) IPCC Special Report on the Ocean and Cryosphere in a Changing Climate. In press. https://www.ipcc.ch/site/ assets/uploads/sites/3/2019/11/03_SROCC_SPM_FINAL.pdf. Accessed on 28 March 2020

JICA, Fiji Ministry of Agriculture, Fisheries and Forests, Yachiyo Engineering Co., Ltd (1998) The study of watershed management and flood control for the four major Viti Levu rivers in the Republic of Fiji Islands. Japan International Cooperation Agency, Suva. https://openjicareport.jica.go.jp/pdf/11463494_ 01.pdf. Accessed on 22 Apr 2020
Jenkins PA (2009) Upstream-downstream: wetlands connect us all. Wetlands International-Oceania, Suva. https://www.ramsar.org/ sites/default/files/documents/pdf/wwd/9/wwd2009_rpts_fiji02. pdf. Accessed on 11 May 2020

Judson S, Ritter DF (1964) Rates of regional denudation in the United States. J Geophys Res 69:3395-3401. https://doi.org/ 10.1029/JZ069i016p03395

Kablan MKA, Dongo K, Coulibaly M (2017) Assessment of social vulnerability to flood in urban Côte d'Ivoire using the MOVE framework. Water 9:292. https://doi.org/10.3390/w9040292

Karamouz M, Zahmatkesh Z (2017) Quantifying resilience and uncertainty in coastal flooding events: framework for assessing urban vulnerability. J Water Resour Plan Manag 143:04016071. https://doi.org/10.1061/(ASCE)WR.1943-5452.0000724

Karmaoui A, Balica S (2019) A new flood vulnerability index adapted for the pre-Saharan region. Int J River Basin Manag 19:93-107. https://doi.org/10.1080/15715124.2019.1583668

Kelman I (2018) Lost for words amongst disaster risk science vocabulary? Int J Disaster Risk Sci 9:281-291. https://doi.org/ 10.1007/s13753-018-0188-3

Kistemann T, Claßen T, Koch C, Dangendorf F, Fischeder R et al (2002) Microbial load of drinking water reservoir tributaries during extreme rainfall and runoff. Appl Environ Microbiol 68:2188-2197. https://doi.org/10.1128/AEM.68.5.2188-2197. 2002

Komi K, Amisigo BA, Diekkrüger B (2016) Integrated flood risk assessment of rural communities in the Oti River Basin. West Africa Hydrol 3:42. https://doi.org/10.3390/hydrology3040042

Lata S, Nunn P (2012) Misperceptions of climate-change risk as barriers to climate-change adaptation: a case study from the Rewa Delta, Fiji. Clim Change 110:169-186. https://doi.org/10.1007/ s10584-011-0062-4

Liu J, Shi ZW (2017) Quantifying land-use change impacts on the dynamic evolution of flood vulnerability. Land Use Policy 65:198-210. https://doi.org/10.1016/j.landusepol.2017.04.012

McGree S, Yeo SW, Devi S (2010) Flooding in the Fiji Islands between 1840 and 2009 (Technical Report of Fiji Meteorological Service). https://doi.org/10.13140/RG.2.2.24364.67202

Metzger MJ, Schröter D (2006) Towards a spatially explicit and quantitative vulnerability assessment of environmental change in Europe. Reg Environ Chang 6:201-216. https://doi.org/10.1007/ s10113-006-0020-2

Mirza MMQ (2011) Climate change, flooding in South Asia and implications. Reg Environ Chang 11:95-107. https://doi.org/10.1007/ s10113-010-0184-7

Mondal MSH, Murayama T, Nishikizawa S (2020) Assessing the flood risk of riverine households: a case study from the right bank of the Teesta River, Bangladesh. Int J Disaster Risk Reduction 51:101758. https://doi.org/10.1016/j.ijdrr.2020.101758

Moreira LL, de Brito MM, Kobiyama M (2021a) A systematic review and future prospects of flood vulnerability indices. Nat Hazard 21:1513-1530. https://doi.org/10.5194/nhess-21-1513-2021

Moreira LL, de Brito MM, Kobiyama M (2021b) Effects of different normalization, aggregation, and classification methods on the construction of flood vulnerability indexes. Water 13:98. https:// doi.org/10.3390/w13010098

Nasiri H, Yusof MJM, Ali TAM (2016) An overview to flood vulnerability assessment methods. Sustain Water Resour Manag 2:331336. https://doi.org/10.1007/s40899-016-0051-x

Nath D (2008) Fiji Water and Sewerage Department: Waila water safety plan. WAF, Suva. http://www.pacificwater.org/userfiles/file/ Waila\%20Water\%20Safety\%20Plan.pdf. Accessed on 31 Mar 2020

Nausori Town Council (2012) Weather and climate. Nausori Town Council. http://nausoritowncouncil.org/weather-climate/. Accessed on 21 May 2020 
Nazeer M, Bork HR (2019) Flood vulnerability assessment through different methodological approaches in the context of northwest Khyber Pakhtunkhwa. Pakistan Sustain 11:6695. https://doi.org/ $10.3390 /$ su 11236695

NDMO (2019) What are floods? National Disaster Management Office, Suva. http://www.ndmo.gov.fj/images/Hazards/Pull-up-banner_ Floods.pdf. Accessed on 20 May 2020

Nepal S, Flügel WA, Shrestha AB (2014) Upstream-downstream linkages of hydrological processes in the Himalayan region. Ecol Process 3:19. https://doi.org/10.1186/s13717-014-0019-4

Nguyen CT, Van Nguyen B (2019) Application of flood vulnerability index in flood vulnerability assessment: a case study in Mai Hoa Commune, Tuyen Hoa District, Quang Binh Province. Sustain Water Resour Manag 5:1917-1927. https://doi.org/10.1007/ s40899-019-00337-y

Nunn PD (2009) Responding to the challenges of climate change in the Pacific Islands: management and technological imperatives. Climate Res 40:211-231. https://doi.org/10.3354/cr00806

Nunn PD (2013) The end of the Pacific? Effects of sea level rise on Pacific Island livelihoods. Singap J Trop Geogr 34:143-171. https://doi.org/10.1111/sjtg.12021

Pattison I, Lane SN (2012) The link between land-use management and fluvial flood risk: a chaotic conception? Prog Phys Geogr 36:72-92. https://doi.org/10.1177/0309133311425398

Polsky C, Neff R, Yarnal B (2007) Building comparable global change vulnerability assessments: the vulnerability scoping diagram. Glob Environ Chang 17:472-485. https://doi.org/10.1016/j.gloen vcha.2007.01.005

Qasim S, Khan AN, Shrestha RP, Qasim M (2015) Risk perception of the people in the flood prone Khyber Pakhtunkhwa Province of Pakistan. Int J Disaster Risk Reduction 14:373-378. https://doi. org/10.1016/j.ijdrr.2015.09.001

Rashni B (2020) Freshwater Invertebrate Assemblages and Ecological Status of the Ba River, Fiji (First series technical consultation of the Regional Scientific and Technical Committee for the GEF Pacific Ridge to Reef Program, Session 2, Topic 2). Global Environmental Facility, Nadi. https://www.pacific-r2r.org/sites/defau 1t/files/2020-03/RSTC-TC-SI-WP.\%207_Session\%202\%20-\% 20Topic\%202\%20Freshwater\%20Invertebrate\%20Assemblages\% 20and\%20Ecological\%20Status\%20of\%20the\%20Ba\%20River\% 2C\%20Fiji\%20\%28revised\%29.pdf. Accessed on 12 June 2020

Robson AJ (2002) Evidence for trends in UK flooding. Philos Trans A Math Phys Eng Sci 360:1327-1343. https://doi.org/10.1098/ rsta.2002.1003

Smit B, Wandel J (2006) Adaptation, adaptive capacity and vulnerability. Glob Environ Chang 16:282-292. https://doi.org/10.1016/j. gloenvcha.2006.03.008

SPC (2016) Community based climate change vulnerability assessment of the Sabeto catchment: enhancing community adaptation to climate change. Secretariat of the Pacific Community, Suva. http://ccprojects.gsd.spc.int/documents/new_docs/14_04/Sabeto\% 20PRA\%20report.pdf. Accessed on 20 June 2020

SPC, SPREP, GIZ (2016) Integrated Vulnerability Assessment Framework for Atoll Islands: a collaborative approach. Secretariat of the Pacific Community, Secretariat of the Pacific Regional Environment Program and Deutsche Gesellschaft für Internationale Zusammenarbeit GmbH. http://ccprojects.gsd.spc.int/documents/ new_docs/14_04/web_\%20IVA_Framework_for_Atoll_Islands_ FINAL.pdf. Accessed on 12 Jan 2020

SPC, World Meteorological Organization, United Nations Educational, Scientific and Cultural Organization, European Union (2012) Catalogue of rivers for Pacific Islands. Secretariat of the Pacific Community. http://pacificwater.org/_resources/article/files/Binde r1.pdf. Accessed on May 152021

SPREP (2014) Fiji's State of Environment Report 2013. Secretariat of the Pacific Regional Environment Program, Apia. http://
macbio-pacific.info/wp-content/uploads/2017/08/State-of-Envir onment-Report-2013.pdf. Accessed on 19 December 2019

Staudt A, Leidner AK, Howard J, Brauman KA, Dukes JS et al (2013) The added complications of climate change: understanding and managing biodiversity and ecosystems. Front Ecol Environ 11:494-501. https://doi.org/10.1890/120275

Terry JP, Garimella S, Kostaschuk RA (2002) Rates of floodplain accretion in a tropical island river system impacted by cyclones and large floods. Geomorphology 42:171-182. https://doi.org/10. 1016/S0169-555X(01)00084-8

Thulstrup AW (2015) Livelihood resilience and adaptive capacity: tracing changes in household access to capital in Central Vietnam. World Dev 74:352-362. https://doi.org/10.1016/j.worlddev.2015.05.019

UNDRR (2017) Terminology for Disaster risk reduction. United Nations Office for Disaster Risk Reduction, Geneva. https://www. undrr.org/terminology. Accessed on 14 June 2021

United Nations Environment Programme (UNEP) (2012) Freshwater under Threat Pacific Islands: Vulnerability Assessment of Freshwater Resources to Environmental Change. South Pacific Community Applied Geoscience and Technology Division, Suva. https://reliefweb.int/sites/reliefweb.int/files/resources/Freshwater Under_Threat-Pacific_Islands.pdf. Accessed on 17 June 2021

Van Aalst MK, Cannon T, Burton I (2008) Community level adaptation to climate change: the potential role of participatory community risk assessment. Glob Environ Chang 18:165-179. https://doi.org/ 10.1016/j.gloenvcha.2007.06.002

Warrick O, Aalbersberg W, Dumaru P, McNaught R, Teperman K (2017) The Pacific adaptive capacity analysis framework: guiding the assessment of adaptive capacity in Pacific Island communities. Reg Environ Chang 17:1039-1051. https://doi.org/10.1007/ s10113-016-1036-x

Weir T, Dovey L, Orcherton D (2017) Social and cultural issues raised by climate change in Pacific Island countries: an overview. Reg Environ Chang 17:1017-1028. https://doi.org/10.1007/ s10113-016-1012-5

Weir T, Pittock J (2017) Human dimensions of environmental change in small island developing states: some common themes. Reg Environ Chang 17:949-958. https://doi.org/10.1007/ s10113-017-1135-3

Weis SWM, Agostini VN, Roth LM, Gilmer B, Schill SR et al (2016) Assessing vulnerability: an integrated approach for mapping adaptive capacity, sensitivity, and exposure. Clim Chang 136:615-629. https://doi.org/10.1007/s10584-016-1642-0

Wheater H, Evans E (2009) Land use, water management and future flood risk. Land Use Policy 26:S251-S264. https://doi.org/10. 1016/j.landusepol.2009.08.019

Wilson L (1973) Variations in mean annual sediment yield as a function of mean annual precipitation. Am J Sci 273:335-349. https:// doi.org/10.2475/ajs.273.4.335

Wishart D, Warburton J, Bracken L (2008) Gravel extraction and planform change in a wandering gravel-bed river: The River Wear, Northern England. Geomorphology 94:131-152. https://doi.org/ 10.1016/j.geomorph.2007.05.003

Woodward G, Bonada N, Brown LE, Death RG, Durance I et al (2016) The effects of climatic fluctuations and extreme events on running water ecosystems. Philos Trans Royal Soc Biol Sci 371:20150274. https://doi.org/10.1098/rstb.2015.0274

Yohe G, Tol RS (2002) Indicators for social and economic coping capacity-moving toward a working definition of adaptive capacity. Glob Environ Chang 12:25-40. https://doi.org/10.1016/ S0959-3780(01)00026-7

Publisher's note Springer Nature remains neutral with regard to jurisdictional claims in published maps and institutional affiliations. 